Original Article

\title{
DEVELOPMENT AND PSYCHOMETRIC EVALUATION OF THE TOOL APTITUDE TOWARDS NURSING
}

\author{
Maxie Andrade ${ }^{1} \&$ Anice George ${ }^{2}$ \\ ${ }^{1}$ Asst. Professor, ${ }^{2}$ Dean, M anipal College of Nursing, \\ Manipal University, Manipal, \\ Correspondence: \\ Maxie Andrade
}

Asst. professor, M anipal College of Nursing, M anipal University, M anipal. E-mail : amaxie@ hotmail.com

\begin{abstract}
:
Nursing is an attribute expected of every living being and every living being is capable of providing care to another in need. Few occasions especially the sickness, unawareness or disability call for special skills of nursing to substitute or supplement to the acute or chronic need of a living being. These skills can be acquired only through special training through a well planned curriculum. Hence in modern medicine, a group of health care providers called nurses are trained to care for the sick and the needy.

Nursing profession has been the attraction for many young adults, however, this attraction has become the passion for some, while for few others, it is still an occupation. The transformation into an effective nurse demands special psychomotor abilities. The transformation is easier and can happen at a faster pace if one possesses an aptitude towards nursing. This assumption led the researcher to develop a tool to identify such able candidates for the profession of nursing. This article explores researcher's two attempts in developing the tool, which were though not fruitful, they certainly have given an impression on the complexity of the measurement of the construct of nursing and caring.
\end{abstract}

Keywords: Aptitude towards nursing, caring, tool development

\section{Introduction:}

Education is a human right and is open for every desiring citizen. It is the foundation for national growth. Diversity in medical education has opened newer courses and professional groups in health sector. Indian universities admit good number of medical and paramedical students to various courses, producing a large number of graduates. There are many who choose a profession out of their own interest, whereas some desire to explore a particular field and quit, thinking, that is not what they are good at. There are a few who leave their decisions on their loved ones and take up the profession but remain totally dissatisfied to continue in the same profession or struggle to exist in the same.

Access this article online Quick Response Code

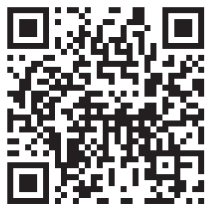

Aptitude is a condition, a quality or a set of qualities in an individual which is indicative of the probable extent to which one will be able to acquire under suitable training some knowledge, skill or composite of knowledge, understanding and skill. The chief value of aptitude testing is in fact that it enables us to pick out from those who do not yet have the ability to perform certain skills; those who with a reasonable amount of training will be most likely to acquire the skills in question and acquire them to a desirable level of a proficiency. Testing aptitude of students during admission to a professional course has been a far thought of the educational administrators, who strongly believe that aptitude of the students can be measured and moreover it is useful for the students to succeed in their career. Standardized Aptitude tests for several occupations are available and are in use; however nursing is in the look out of the same. ${ }^{1,2,3 .}$

Nursing is a practice oriented profession and the core of nursing is care. Nursing is both an art and a science and the nursing education includes the knowledge and skills from the basic, behavioural and applied sciences. There is remarkable progress in health sector and health care knowledge. Nurses remain with clients round the clock in the in-patient setting and are required to exhibit 
competent care. Nurses have to rationalize actions and act, because they are accountable and responsible for each action. Thus nursing is challenging and to face the challenges, one has to have a favourable attitude and aptitude towards nursing. ${ }^{4}$

High Power Committee on nursing and nursing profession, appointed by Government of India, M inistry of Health and Family Welfare, in its report in 1990 stated, "Nursing personnel should have a complete say in matters of selection of students, which should be based on merit. Aptitude tests should be introduced for selection of candidates." In a study titled, perceptions on nurses, nursing practice and nursing education system (2010), one of the physicians was of the opinion that nursing students' aptitude should be assessed. He said:"Practicing nurses need qualities like 'care and compassion' without which no amount of education can help. A study held in Bangalore, India on aptitude towards nursing among nursing professionals' recommended to test the aptitude of students at entry level. ${ }^{25,6,7}$

The alarming increase in the number of unemployed graduate nurses during the past three decades has caused the heads of professional schools to seek means of identifying students who will be able to measure up to the higher standards necessary if the profession of nursing is to maintain its position in the fields of medical and social service. Such identifications, to be effective, must be made prior to admission to schools of nursing. The alternative method of selecting qualified nurses by permitting them to "try" nursing for one, two or three years before being rejected is too wasteful of time, money, and morale. Thus the problem becomes one of testing for nursing aptitude at the time a candidate applies for admission to a school/college of nursing. It may seem that the task of identifying students with aptitude for nursing is a simple one wherein a nurse administrator looks at and talk to an applicant and differentiates the able from the unable candidates. But the task is not that easy. It becomes necessary, therefore, to use the painstaking methods of research to discover more dependable methods to identify the most suitable candidates and predict their stay in the profession. $^{2}$

A number of attempts have been made to develop tools to assess nursing aptitude. However the review reveals that these attempts are either to assess the specific ability such as math or science aptitude or for selecting students to the upper nursing division Aptitude continues to be predictive of BSN (Bachelor of Science in Nursing) students success, even as BSN student demographics and pre-nursing educational backgrounds change. Authors discuss that nurse educators should focus their attention on core predictor variables that are known and that continue to be predictive of BSN student attrition. BSN students to have holistic knowledge necessary for safe and efficient nursing practice; they must have not only a sufficient math aptitude to do clinical calculations but also the ability to read at the level demanded by the clinical questions being posed. ${ }^{8,9}$

The Aptitude test developed by the Asian Psychological Services and Assessment, Inc., admits that the ANP (Assessment of Nursing Potential) is a valid and reliable measure to form a strong base for selecting students for admission to the upper nursing division level. It is composed of a combination of three tests, namely: (1) Nursing attitudinal inventory (earlier known as the Nursing Quality Scale) which assesses the traits that are essential in contributing to one's success in the nursing profession; (2) Aptitude test that measures the "innate-based" learned abilities; and (3) Achievement test measuring what has been learnt in the lower nursing division level. The ANP test battery has been widely used by nursing schools in the Philippines. It is the only locally made test used for selection and placement of nursing students. It has been seen as a good preparation for the Nursing Board Examinations and foreign-based tests such as the NCLEX and CGFNS ${ }^{10}$

The review of literature suggested that nursing is yet to find a tool to assess the aptitude of nursing students at entry level and this encouraged the researcher to attempt development of a tool for this purpose. Currently, majority 
of Schools and Colleges of Nursing in India admit students purely on their pre university course marks. A very few have an entrance examination for undergraduate or diploma courses. M ost of the personal interviews held at the time of admission are not true counseling sessions per se in most of the nursing schools and colleges. There is dissatisfaction expressed by experienced clinical nurses on the ability of graduated nurses to function effectively in clinical nursing practice. However, in these contexts, assessment of aptitude at the time of admission to nursing courses is believed to be useful in selection of right candidates for nursing courses.

\section{Materials, Methods and Results:}

The study assumed that aptitude is the product of innate and acquired abilities and is measurable.

Table 1 summarizes the first attempt. The subscales selected for the tool were based on the Philippines study (Assessment of Nursing Potential) and the items were developed based on those operational definitions. However these tools were not comparable as the purpose for which the tools were developed and items were different. There were eight subscales in the developed tool namely, caring, compassion, connectedness, commitment, abstract reasoning, academic aptitude, reading comprehension and verbal ability and vocational adjustment.

The items in the academic aptitude and abstract reasoning were based on the 12th standard syllabi and the items were from the Science subject including Environment and biodiversity. Content validation was done by 11 experts: Clinical Psychologist (2); Professors teaching at PU college (2); and Nursing doctorates (7). Two validators suggested to use care scenarios than the likert scale alone, thus two scenario based subscales for caring were developed and revalidated among 5 nursing experts. The samples were first year nursing students (diploma and B. Sc.) who were admitted to the course a month ago, in the Schools and Colleges of Nursing in Udupi and South Canara districts of Karnataka. Official permission from Heads of Institutions and informed consent from partcipants were obtained. The average time taken by the participants to complete the questionannire was 85 minutes. The Cronbach's alpha for the overall likert scale for 108 items was $r=0.932$; overall scale test retest reliability (with a gap of 8 days between tests) was $r=0.7$. The overall Split half reliability of MCQ items (caring scenario $1 \& 2$, abstract reasoning, academic aptitude, reading comprehension, verbal ability) was $r=$ 0.42 .

Though the overall scale and test retest reliability were in the acceptable range, it was decided to condense the tool as time for administration was nearly 85 minutes. There were three decisions taken after the first attempt for the modification of the tool as follows.

1. An opinion on excluding the subscale of academic aptitude was considered apt as the same is projected in the report card (pre-university) of the student. Moreover, as these items were based on 'science' subjects, there is likelihood that the art and commerce background students (of few diploma nursing students) may either guess answers or show no interest in attempting for the items. However the pilot study scores revealed that even students with science background could not perform on these items better.

2. One of the nursing experts from USA opined that, "English is not the primary language in India, and hence assessment of verbal ability and reading comprehension at pre entry level may not be commendable." This suggestion was considered apt as in Karnataka, there are few students (Arts, Science, Commerce) who enter nursing with Kannada as the medium of instruction in their preuniversity programme. M oreover majority of students who study nursing in Karnataka, are from the neighboring state of Kerala, where also similar options for the choice of the medium of instruction exist. Thus the suggestion of the expert was considered valid, as there is scope of development of this ability during the course even if it is not possessed at entry level. (The medium of instruction for diploma and graduate nursing programmes in India is English and English is taught as a subject in the first year of 
the nursing course).

3. Nursing requires scientific knowledge but nursing is also an art. Nursing is a team work and the independent life saving decisions taken by nurses are of less complexity in public health care practice. In hospital settings, the health team is available within the reachable distance. The absence of abstract reasoning ability from nursing students at basic level will be supplemented by the health team members in clinical practice. Abstract reasoning is nurtured through experience and this will be developed as students undergo the training programme. Assessing these at pre entry level may give more importance to science than the art form of nursing.

Considering these suggestions, a second attempt was made and a tool was prepared with the components presented in table 2 . The subscale on reading comprehension was retained as it was believed that nursing students are taught the course in English. The items of the likert scale namely caring, compassion, connectedness and vocational adjustment were modified as per the item analysis findings of the first attempt. The component of commitment was clubbed with vocational adjustment in a separate section as part 2. (Part 1 was named as adaptation) Caring scenarios were framed as decision making ability items which included eight M CQ on positioning and feeding a bedridden adult in a family setting. Pictorial presentations were presented in order to assess visual-spatial abilities, e.g.: reading of a thermometer, graphic recording, selection of accessories/supplies for a equipment (based on the diameter of tips) or for simple dressing of a minor wound or hand hygiene. Abstract reasoning was replaced with Arithmetic ability, assuming nurses need to possess this ability as medication errors are considered serious errors in nursing. The items were pretested for readability and were given to seven experts for content validation (Two clinical psychologists and five nursing doctorates). The tool was administered in a group, ensuring a minimum distance of 3 feet between participants to avoid discussion and copying. Table 2 summarizes the findings.
The test-retest reliability of this scale was not tested, as the reliability of the subscales were comparatively lower as compared to the first attempt. The split half reliability of MCQ items was found to be comparatively better $(r=0.7)$. The comparison of means of each subscale (presented in table 3) revealed that there was significant difference between the groups in caring, reading comprehension, vocational adjustment(commitment) and mechanical ability.

The researcher planned to pretest the same tool among the public (receptionists and clerks), the students of other courses in health care (Respiratory therapy and Health Information System), the practicing nurses of a selected teaching hospital, second, third and fourth year students of diploma and B. Sc. Nursing courses of a nursing School and College attached to the same teaching hospital in Udupi District. The tool was administered after obtaining the informed consent and official permission from respective authorities, in a group under supervision, ensuring no copying or discussion among participants. The tool took 50 minutes for its completion on an average. The public group was administered only the likert scale. An analysis of the findings is presented in table 4. Analysis of scores of students year wise is shown in table 5 and 6 for B. Sc. Nursing and diploma nursing students respectively. Though the scale appeared handy to administer within an hour, the findings were not suggestive of acceptable reliability (at least $r=0.6$ for each subscale).

Table 4 reveals that difference was found in commitment and mechanical ability among groups however the abilities of staff nurses and the final year B. Sc. Nursing students were a near match.

Table 5 shows that there was significant difference in the scores of B. Sc. Nursing students year wise. Post hoc test revealed difference in scores of caring, arithmetic and mechanical ability between all four groups; compassion between $1^{\text {st }}$ and $3^{\text {rd }}$ as well as $3^{\text {rd }}$ and $4^{\text {th }}$ year; connectedness between $1^{\text {st }}$ and fourth as well as $2^{\text {nd }}$ and $3^{\text {rd }}$; adaptation between $1^{\text {st }}$ and $3^{\text {rd }}$ as well as $1^{\text {st }}$ and $4^{\text {th }}$; commitment between $1^{\text {st }}$ and $3^{\text {rd }}$ as well as $3^{\text {rd }}$ and $4^{\text {th }}$; reading 
comprehension in $3^{\text {rd }}$ and $4^{\text {th }}$; decision making between $1^{\text {st }}$ and $4^{\text {th }}$ year students. There was significant difference in total scores of reading, arithmetic, decision making and mechanical ability among all four year students, whereas in total scores of caring, compassion, commitment, connectedness and adaptation, there was difference in $1^{\text {st }}$ and $3^{\text {rd }}$ as well as $1^{\text {st }}$ and $4^{\text {th }}$ years; $2^{\text {nd }}$ and $4^{\text {th }}$ years as well as $3^{\text {rd }}$ and $4^{\text {th }}$ year students. Among diploma students in table 6 , significant difference was noted only in adaptation among all three batches and reading comprehension in $1^{\text {st }}$ and $2^{\text {nd }}$ year students as revealed through the post hoc test.

The assessments in second attempt revealed that nursing entrants of diploma and graduate nursing program differed in key abilities of caring and commitment wherein the mean scores of caring were higher among diploma students compared to that of graduate programme and vice versa was true with regard to commitment. The difference was notable in terms of reading and mechanical abilities which were attributable to their background in pre university education. The difference in caring and commitment was not acceptable by the researcher as these were considered important qualities of a nurse.

At the end of the second attempt, researcher thought to seek answer to a question, "What abilities one should look for among pre entry students apart from caring?" A survey was held among the Professors ( $n=7$ ) of a selected college and two external experts. The experts were not comfortable to pinpoint the abilities, however agreed on the variables listed as subscales in the second attempt. There was no unanimous agreement on the assigned weightage, however five of them weighed decision making and caring $25 \%$ each. However one of the external expert (from USA) opined that though nursing is art and science, the science component of nursing should be assigned a weightage of $65 \%$, which includes, arithmetic, decision making, mechanical and verbal abilities. One of the Professors from India (externl expert) gave a higher rating (90\%) for caring and the Professors of the selected college ranked each ability between $10-20 \%$.

Thus the section of arithmetic ability, decision making, reading comprehension and mechanical ability were retained as a part of the tool and it was decided to pretest the same with first year graduate students of arts, commerce and science stream after obtaining the official permission from the college authority and participants. As construct validity of the scale in second attempt was not testable because the items were not based on a sound theory, the third attempt was made to base it on Swanson's theory of caring, and this attempt is not described in this article. $^{11}$

\section{Discussion :}

The idea of measurement of aptitude towards nursing has been though suggested by the high power committee before 20 years, review reports two such attempts made in India to measure it scientifically. As discussed in the introduction, the published aptitude measurement scales outside India, had not been tested for their efficacy in selection of nursing students. The nursing institutes abroad, seem to be assessing nursing aptitude at entry level however published reports on their efficacy are not found.

Nursing Aptitude test (NAT) for students seeking admission to nursing institutes was attempted by Triza Jiwan (2011) who found the reliability $(\alpha)$ of $r=0.85$ for cognitive and affective aptitude as well as 0.72 for conative aptitude. The one hour paper and pencil test was built around intelligence, emotional strength and psychomotor skills. The article reports that it was built on a theory and construct validity of the tool was tested on 10 experts. However the materials, methods used and the theory on which the tool was developed and tested is not clear in the report. $^{12}$

A study by Pataliah used the subscales of memory, knowledge, vocabulary, judgment in nursing situation, ability to comprehend instructions and follow. The study used reading and verbal ability as well, however the assessment of these abilities in the current study did not display good aptitude. The current study found majority of the entrants to nursing courses were females $(95.7 \%$ in first attempt; $98.8 \%$ in second attempt) and Christians (61\% in 
$1^{\text {st }}$ attempt; $55.6 \%$ in second attempt) which is very evident in most of the nursing studies. ${ }^{7,13}$

Existing Aptitude tests have been well critiqued by several authors. A study of UK concludes stating UKCAT (United Kingdom Clinical Aptitude Test) scores are predictive of Year 1 and 2 examination performance at medical school, whereas interview scores are not. The results challenge, claims made by other authors that aptitude tests do not have a place in medical school selection in the UK. ${ }^{3}$

In an article David McDonald discussed on the role of intelligence and aptitude tests and how they are to be interpreted. The steps delineated by the author in development of an aptitude test, are commendable. In nursing, the psychomotor skills required are numerous though not complex. However, the introduction of technology in health care today especially in nursing situations, has brought in complexity thereby welcoming technical competency in nurses. The major areas which require clarity in nursing would be professional boundary and specificity of psychomotor skills. M ost of the nursing responsibilities in today's health practice is shared by several allied professionals, moreover complexity of skills are not similar in different nursing units, let that be adult or pediatric, family, community or institution based settings. ${ }^{14}$

Caring has been conceptualized as the central and significant factor in nursing science and patient healing. However is caring measurable? Jean Watson, a pioneer in caring science states, "Caring instruments serve as indicators along the way and point back to a deeper dimension of human caring relational practices, which remain forever elusive and non-measurable. Deep philoso phical ethical and ontological subjective dimension of caring cannot be measured, but some measurement can elucidate the manifest field of caring practices, while some pointing towards the non-manifest whole." The complexity in finding the construct validity for the caring phenomena justifies Dr. Watson's statement however, painstaking efforts need to be ongoing and continued to capture the meaning of the construct to the extent possible and to be included as a measure to wards nursing aptitude. ${ }^{15}$
Nursing is a skill and assessment of nursing potential has been the need of the hour in Indian context. General aptitude tests are available and are widely used, however growing complex health care industry of today is in the lookout for efficient and effective nurses, who touch the lives of patients shortening their length of stay. Nurses with nursing aptitude may fit well in this caring industry and moreover nurse trainers may find it easy to mould these nurses at a faster rate to meet the increased demand for nurses worldwide. Screening entrants to nursing does not mean to close the door for those who are interested but do not have the right aptitude, however this screening is only to prevent burnout from repeated trying. The entrant when finds herself/himself capable to nurture the existing skill to the level required may find the profession enjoyable and aid growth of the profession.

\section{Conclusion:}

M easurements in psychosocial sciences have been tried to simplify the understanding of the concept or construct. The effectiveness of nursing is largely dependent on the psychosocial elements of care. Nursing is a broad concept and a construct (as a verb and noun), which employ comparatively simple motor skills. Nursing is a universal phenomena and ina broader sense it is self transcendence. The complexity of nursing is in its contextual factors, which vary in settings and from person to person. Nursing is percieved and experienced differently by different people that is how measurement of aptitude towards nursing has appeared complex.

\section{Acknowledgment :}

The investigators thank the participants and the validators of the tool. Special thanks to administrative authorities of institutions for permission to conduct the study and for providing the necessary physical environment for administration of the tool. 
Table 1: Components and reliability of the tool: Nursing aptitude

\begin{tabular}{|c|c|c|c|c|c|c|}
\hline Subscales & $\begin{array}{c}\text { Number of } \\
\text { items }\end{array}$ & $\begin{array}{c}\text { Range of } \\
\text { scores }\end{array}$ & Sample & Reliability & $\begin{array}{l}\text { Median } \\
\text { (Range) }\end{array}$ & M ean (SD) \\
\hline $\begin{array}{l}\text { Caring* } \\
\text { (Personal attributes) }\end{array}$ & 21 & $21-105$ & \multirow{14}{*}{$\begin{array}{c}\text { First } \\
\text { year } \\
\text { B.Sc. } \\
\text { Nursing } \\
\text { students } \\
(n=51) \\
\\
\text { First } \\
\text { year } \\
\text { diploma } \\
\text { Nursing } \\
\text { students } \\
(n=42)\end{array}$} & 0.726 & $\begin{array}{c}52 \\
(54)\end{array}$ & $\begin{array}{c}52.48 \\
(10.547)\end{array}$ \\
\hline Caring scenario 1 & 10 & $0-10$ & & 0.296 & $\begin{array}{c}4 \\
(8)\end{array}$ & $\begin{array}{c}4.29 \\
(1.639)\end{array}$ \\
\hline Caring scenario 2 & 6 & $2-12$ & & 0.331 & $\begin{array}{c}9 \\
(10)\end{array}$ & $\begin{array}{c}8.83 \\
(1.993)\end{array}$ \\
\hline Compassion* & 16 & $16-80$ & & 0.755 & $45(43)$ & 43.54(8.436) \\
\hline Commitment* & 22 & $22-110$ & & 0.833 & $61(72)$ & 59.73(11.31) \\
\hline Connectedness* & 20 & $20-100$ & & 0.858 & $60(69)$ & $58.48(10.389)$ \\
\hline Abstract reasoning & 10 & $0-10$ & & $0.219 \#$ & $3(6)$ & \begin{tabular}{|l|}
$3.09(1.544)$ \\
\end{tabular} \\
\hline Academic aptitude & 45 & $0-45$ & & $0.446 \#$ & $11(18)$ & $11.39(3.884)$ \\
\hline Reading Comprehension & 5 & $0-5$ & & $0.274 \#$ & $2(4)$ & $2.38(1.031)$ \\
\hline Verbal comprehension & 06 & $0-6$ & & $0.009 \#$ & $3(5)$ & $2.56(1.058)$ \\
\hline $\begin{array}{l}\text { Verbal comprehension } \\
\text { (reading a passage) }\end{array}$ & 04 & $0-4$ & & $0.026 \#$ & $1(3)$ & $1.32(0.874$ \\
\hline $\begin{array}{l}\text { Vocational adjustment* } \\
\text { (Social relationships) }\end{array}$ & 11 & $11-55$ & & 0.810 & $32(35)$ & $31.45(6.618)$ \\
\hline $\begin{array}{l}\text { Vocational adjustment* } \\
\text { (Academic) }\end{array}$ & 10 & $10-50$ & & 0.795 & $29(35)$ & $28.39(6.33)$ \\
\hline $\begin{array}{l}\text { Vocational Adjustment* } \\
\text { (Personal emotional) }\end{array}$ & 8 & $8-40$ & & 0.734 & $24(28)$ & $23.54(4.736)$ \\
\hline
\end{tabular}

* Five point likert scale: Never, Rarely, Occasionally, M ost of the times, Always

\#Split half reliability

Table 2: Components and reliability of the tool: Nursing aptitude

\begin{tabular}{|c|c|c|c|c|c|c|}
\hline Subscales & $\begin{array}{c}\text { Number of } \\
\text { items }\end{array}$ & $\begin{array}{c}\text { Range of } \\
\text { scores }\end{array}$ & Sample & Reliability & $\begin{array}{l}\text { Median } \\
\text { (Range) }\end{array}$ & M ean (SD) \\
\hline Caring & 15 & $15-75$ & \multirow{5}{*}{$\begin{array}{c}\text { B.SC. } \\
\text { Nursing } \\
\text { first year } \\
(n=86)\end{array}$} & 0.707 & $62(34)$ & $61.4(6.185)$ \\
\hline Compassion & 18 & $18-90$ & & 0.568 & $67(41)$ & $66.53(7.234)$ \\
\hline Connectedness & 22 & $22-110$ & & 0.543 & $86(35)$ & $84.84(6.933)$ \\
\hline Vocational adjustment & 17 & $17-85$ & & 0.594 & $65(44)$ & $64.20(6.834)$ \\
\hline (Part 1) & & & & & & \\
\hline Vocational adjustment & 9 & $9-45$ & \multirow{8}{*}{$\begin{array}{c}\text { Diploma } \\
\text { nursing } \\
(\mathrm{n}=38)\end{array}$} & 0.530 & $33(25)$ & $32.41(4.976)$ \\
\hline (Part 2) & & & & & & \\
\hline Reading comprehension & 6 & $0-6$ & & $0.577^{* *}$ & $3(6)$ & $2.96(1.605)$ \\
\hline Decision making ability & 8 & $0-8$ & & $0.048^{* *}$ & $3(6)$ & $2.85(1.338)$ \\
\hline Mechanical ability & 8 & $0-23$ & & $0.296 * *$ & $12(19)$ & $11.47(4.205)$ \\
\hline Arithmetic ability & 8 & $0-8$ & & $0.322^{* *}$ & $3(8)$ & $2.63(1.6)$ \\
\hline Total\# & 81 & $81-405$ & & 0.846 & $311(144)$ & $309.29(23.909$ \\
\hline Total\#\# & 29 & $0-29$ & & $0.7^{* *}$ & $20(36)$ & 19.9(6.409) \\
\hline
\end{tabular}

* Five point likert scale: Never, Rarely, Occasionally, M ost of the times, Always

** Split half reliability

\#. Total scores of Caring, compassion, connectedness and vocational adjustment

\#\#. Total scores of Reading comprehension, decision making, mechanical and arithmetic ability 
Table 3: Comparison of diploma ( $n=36$ )and B. Sc. Nursing students $(n=86)$ scores

\begin{tabular}{|l|c|c|c|c|}
\hline Subscales & $\begin{array}{c}t \\
\text { V value }\end{array}$ & \multirow{2}{*}{ P value } & \multicolumn{2}{|c|}{ Confidence interval } \\
\cline { 4 - 5 } & $(\mathrm{df=120)}$ & & lower & upper \\
\hline Caring & 2.008 & $\mathbf{0 . 0 4 7}$ & 0.035 & 4.839 \\
\hline Compassion & 1.919 & 0.057 & -5.577 & 0.088 \\
\hline Connectedness & 0.263 & 0.793 & -2.391 & 3.128 \\
\hline Vocational adjustment(Part 1) & 1.869 & 0.064 & -5.087 & 0.146 \\
\hline Vocational adjustment (Part 2) & 4.216 & $\mathbf{0 . 0 0 1}$ & -5.628 & -2.031 \\
\hline Reading comprehension & 6.403 & $\mathbf{0 . 0 0 1}$ & -2.327 & -1.225 \\
\hline Decision making ability & 1.482 & 0.141 & -0.919 & 0.132 \\
\hline Mechanical ability & 6.056 & $\mathbf{0 . 0 0 1}$ & -5.866 & -2.975 \\
\hline Arithmetic ability & 0.572 & 0.568 & -0.810 & 0.447 \\
\hline Total\# & 1.316 & 0.191 & -15.630 & 3.149 \\
\hline Total\#\# & 6.115 & $\mathbf{0 . 0 0 1}$ & -8.966 & -4.580 \\
\hline
\end{tabular}

* Five point likert scale: Never, Rarely, Occasionally, M ost of the times, Always

\#. Total scores of Caring, compassion, connectedness and vocational adjustment

\#. Total scores of Reading comprehension, decision making, mechanical and arithmetic ability.

Table 4: M ean standard deviation of scores on nursing aptitude among health care staff

\begin{tabular}{|c|c|c|c|c|c|c|}
\hline Subscales & $\begin{array}{l}\text { Staff nurses } \\
\qquad(n=58)\end{array}$ & $\begin{array}{l}\text { Clerks } \\
(n=49)\end{array}$ & $\begin{array}{l}\text { Respiratory } \\
\text { therapy } \\
\text { students }(n=14)\end{array}$ & \begin{tabular}{|c|} 
Health \\
information \\
system students \\
$(n=27)$
\end{tabular} & $\begin{array}{l}\text { B. Sc. Nursing } \\
\text { final year } \\
\text { students } \\
(n=85)\end{array}$ & $\begin{array}{c}\text { Diploma } \\
\text { nursing final } \\
\text { year students } \\
(n=48)\end{array}$ \\
\hline Caring & $\begin{array}{c}62.16 \\
(5.547)\end{array}$ & $\begin{array}{c}60.86 \\
(4.912)\end{array}$ & $\begin{array}{c}59.79 \\
(4.886)\end{array}$ & \begin{tabular}{|c|}
60.52 \\
$(4.449)$
\end{tabular} & $\begin{array}{l}63.04 \\
(5.81) \\
\end{array}$ & $\begin{array}{c}62.46 \\
(5.299)\end{array}$ \\
\hline Compassion & $\begin{array}{c}66.81 \\
(6.387)\end{array}$ & $\begin{array}{c}65.08 \\
(6.010)\end{array}$ & $\begin{array}{c}67.14 \\
(5.057)\end{array}$ & $\begin{array}{c}66.22 \\
(6.002)\end{array}$ & $\begin{array}{l}68.28 \\
(5.15)\end{array}$ & $\begin{array}{c}65.31 \\
(7.6)\end{array}$ \\
\hline Connectedness & $\begin{array}{c}90.4 \\
(6.64)\end{array}$ & $\begin{array}{c}84.78 \\
(6.182)\end{array}$ & $\begin{array}{c}85.07 \\
(6.367)\end{array}$ & $\begin{array}{c}87.85 \\
(6.049)\end{array}$ & $\begin{array}{l}89.44 \\
(5.88)\end{array}$ & $\begin{array}{c}87.52 \\
(5.231)\end{array}$ \\
\hline Vocational adjustment(Part 1) & $\begin{array}{l}64.93 \\
(5.69)\end{array}$ & $\begin{array}{c}62.16 \\
(7.198)\end{array}$ & $\begin{array}{c}64.07 \\
(7.385)\end{array}$ & $\begin{array}{c}65.11 \\
(5.033)\end{array}$ & $\begin{array}{c}65.69 \\
(5.604)\end{array}$ & $\begin{array}{c}62.17 \\
(5.737)\end{array}$ \\
\hline Vocational adjustment (Part 2) & $\begin{array}{l}29.83 \\
(3.56)\end{array}$ & $\begin{array}{c}31 \\
(5.091)\end{array}$ & $\begin{array}{l}26.93 \\
(3.54)\end{array}$ & $\begin{array}{c}30.3 \\
(3.582)\end{array}$ & $\begin{array}{c}35.08 \\
(4.124)\end{array}$ & $\begin{array}{c}29.04 \\
(5.251)\end{array}$ \\
\hline Reading comprehension & $\begin{array}{c}3.57 \\
(1.788)\end{array}$ & \multirow{4}{*}{$\begin{array}{c}\text { Not } \\
\text { assessed }\end{array}$} & $\begin{array}{c}3.36 \\
(1.55)\end{array}$ & $\begin{array}{c}3.81 \\
(1.495)\end{array}$ & $\begin{array}{c}4.12 \\
(1.524)\end{array}$ & $\begin{array}{c}2.33 \\
(1.521)\end{array}$ \\
\hline Decision making ability & $\begin{array}{c}3.12 \\
(1.352)\end{array}$ & & $\begin{array}{c}2.79 \\
(0,975)\end{array}$ & $\begin{array}{c}1.96 \\
(1.675)\end{array}$ & $\begin{array}{c}3.66 \\
(1.366)\end{array}$ & $\begin{array}{c}2.29 \\
(1.051)\end{array}$ \\
\hline Mechanical ability & $\begin{array}{c}16.05 \\
(4.438)\end{array}$ & & $\begin{array}{l}11.93 \\
(3.97)\end{array}$ & $\begin{array}{c}7.93 \\
(5.349)\end{array}$ & $\begin{array}{c}15.94 \\
(4.098)\end{array}$ & $\begin{array}{c}8.58 \\
(5.287)\end{array}$ \\
\hline Arithmetic ability & $\begin{array}{c}3.74 \\
(1.702)\end{array}$ & & $\begin{array}{c}3.5 \\
(1.743)\end{array}$ & $\begin{array}{c}1.81 \\
(1.841)\end{array}$ & $\begin{array}{c}3.59 \\
(1.841)\end{array}$ & $\begin{array}{c}2.5 \\
(1.238)\end{array}$ \\
\hline \begin{tabular}{|l|l} 
Total\# \\
\end{tabular} & $\begin{array}{c}314.72 \\
(20.509)\end{array}$ & $\begin{array}{c}303.88 \\
(22.568)\end{array}$ & $\begin{array}{c}303 \\
(18.794)\end{array}$ & $\begin{array}{c}310 \\
(15.214)\end{array}$ & $\begin{array}{c}321.42 \\
(19.678)\end{array}$ & $\begin{array}{l}306.5 \\
(21.5)\end{array}$ \\
\hline 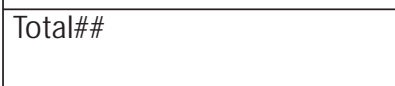 & $\begin{array}{c}26.48 \\
(7.361)\end{array}$ & $\begin{array}{c}\text { Not } \\
\text { applicable }\end{array}$ & $\begin{array}{c}21.57 \\
(5.345)\end{array}$ & $\begin{array}{c}15.52 \\
(8.045)\end{array}$ & $\begin{array}{c}27.33 \\
(6.5)\end{array}$ & $\begin{array}{c}15.71 \\
(5.946)\end{array}$ \\
\hline
\end{tabular}

* Five point likert scale: Never, Rarely, Occasionally, M ost of the times, Always

\#. Total scores of Caring, compassion, connectedness and vocational adjustment

\#\#. Total scores of Reading comprehension, decision making, mechanical and arithmetic ability. 
Table 5:M ean, standard deviation of scores on nursing aptitude of B.Sc. Nursing students

\begin{tabular}{|l|c|c|c|c|c|c|}
\hline Subscales & $1^{\text {st }}$ year $(n=86)$ & $2^{\text {nd }}$ year $(n=48)$ & $3^{\text {rd }}$ year $(n=46)$ & $4^{\text {th }}$ year $(n=85)$ & F Value (df) & P value \\
\hline Caring & 60.67 & 59.33 & 58.07 & 63.07 & 7.747 & 0.001 \\
& $(6.503)$ & $(6.409)$ & $(5.579)$ & $(5.813)$ & $(3,261)$ & \\
\hline Compassion & 67.38 & 66.65 & 63.98 & 68.18 & 4.643 & 0.004 \\
& $(7.439)$ & $(6.466)$ & $(5.741)$ & $(5.157)$ & $(3,261)$ & \\
\hline Connectedness & 84.74 & 85.79 & 83.43 & 89.44 & 11.584 & 0.001 \\
& $(7.346)$ & $(5.996)$ & $(5.905)$ & $(5.883)$ & $(3,261)$ & \\
\hline Vocational & 65.08 & 64.08 & 61.74 & 65.69 & 4.191 & 0.006 \\
\hline adjustment(Part 1) & $(7.151)$ & $(6.86)$ & $(5.523)$ & $(5.604)$ & $(3,261)$ & \\
\hline Vocational & 33.36 & 53.5 & 31.04 & 35.08 & 8.664 & 0.001 \\
\hline adjustment (Part 2) & $(4.636)$ & $(4.292)$ & $(4.158)$ & $(4.124)$ & $(3,261)$ & \\
\hline Reading comprehension & 3.5 & 3.96 & 3.3 & 4.12 & 3.692 & 0.012 \\
& $(1.493)$ & $(1.798)$ & $(1.658)$ & $(1.524)$ & $(3,261)$ & \\
\hline Decision making ability & 2.98 & 3.21 & 3.28 & 3.66 & 3.285 & 0.021 \\
& $(1.447)$ & $(1.487)$ & $(1.486)$ & $(1.368)$ & $(3,261)$ & \\
\hline Mechanical ability & 12.84 & 13.79 & 12.2 & 15.94 & 12.522 & 0.001 \\
& $(3.564)$ & $(3.585)$ & $(4.651)$ & $(4.098)$ & $(3,261)$ & \\
\hline Arithmetic ability & 2.71 & 2.42 & 2.26 & 3.59 & 8.906 & 0.001 \\
& $(1.7)$ & $(1.302)$ & $(1.512)$ & $(1.841)$ & $(3,261)$ & \\
\hline Total\# & 311.55 & 309.35 & 298.26 & 321.42 & 10.688 & 0.001 \\
& $(21.844)$ & $(24.455)$ & $(19.774)$ & $(19.678)$ & $(3,261)$ & \\
\hline Total\#\# & 22.02 & 23.38 & 21.04 & 27.33 & 14.852 & 0.001 \\
& $(5.959)$ & $(5.491)$ & $(6.415)$ & $(6.5)$ & $(3,261)$ & \\
\hline
\end{tabular}

* Five point likert scale: Never, Rarely, Occasionally, M ost of the times, Always. \#. Total scores of Caring, compassion, connectedness and vocational adjustment. \#. Total scores of Reading comprehension, decision making, mechanical and arithmetic ability.

Table 6: M ean, standard deviation of scores on nursing aptitude of diploma students

\begin{tabular}{|l|c|c|c|c|c|}
\hline Subscales & 1st year $(n=38)$ & $2^{\text {nd }}$ year $(n=50)$ & $3^{\text {rd }}$ year $(n=48)$ & F Value(df) & P value \\
\hline Caring & 63.06 & 63.08 & 62.46 & 0.22 & 0.801 \\
& $(5.099)$ & $(4.915)$ & $(5.299)$ & $(2,133)$ & \\
\hline Compassion & 64.61 & 66.10 & 65.31 & 0.509 & 0.603 \\
& $(6.429)$ & $(6.606)$ & $(7.611)$ & $(2,133)$ & \\
\hline Connectedness & 85.05 & 84.96 & 87.52 & 2.894 & 0.059 \\
& $(5.982)$ & $(6.276)$ & $(5.231)$ & $(2,133)$ & \\
\hline Vocational adjustment(Part 1) & 62.21 & 65.38 & 62.17 & 4.631 & $\mathbf{0 . 0 1 1 ^ { * * }}$ \\
& $(5.648)$ & $(6.233)$ & $(5.737)$ & $(2,133)$ & \\
\hline Vocational adjustment (Part 2) & 29.58 & 30.22 & 29.04 & 8.67 & 0.423 \\
& $(4.589)$ & $(3.328)$ & $(5.251)$ & $(2,133)$ & \\
\hline Reading comprehension & 1.74 & 2.38 & 2.33 & 3.489 & $\mathbf{0 . 0 3 3 * *}$ \\
& $(1.107)$ & $(0.987)$ & $(1.521)$ & $(2,133)$ & \\
\hline Decision making ability & 2.55 & 2.28 & 2.29 & 0.767 & 0.466 \\
& $(1.005)$ & $(1.278)$ & $(1.051)$ & $(2,133)$ & \\
\hline Mechanical ability & 8.37 & 9.32 & 8.58 & 0.492 & 0.613 \\
& $(3.921)$ & $(4.963)$ & $(5.287)$ & $(2,133)$ & \\
\hline Arithmetic ability & 2.45 & 2.16 & 2.5 & 0.983 & 0.376 \\
& $(1.35)$ & $(1.267)$ & $(1.238)$ & $(2,133)$ & \\
\hline Total\# & 304.5 & 309.74 & 306.5 & 0.831 & 0.438 \\
& $(18.182)$ & $(17.975)$ & $(21.5)$ & $(2,133)$ & \\
\hline Total\#\# & 15.11 & 16.14 & 15.71 & 0.383 & 0.682 \\
& $(4.572)$ & $(5.675)$ & $(5.946)$ & $(2,133)$ & \\
\hline
\end{tabular}

* Five point likert scale: Never, Rarely, Occasionally, M ost of the times, Always. ** $\mathrm{p} \varangle 0.05$

\#. Total scores of Caring, compassion, connectedness and vocational adjustment

\#\#. Total scores of Reading comprehension, decision making, mechanical and arithmetic ability. 
References:

1. Mangal SL. General Psychology. Fifteenth reprint. New Delhi: Sterling Publishers Pvt. Ltd; 2008

2. Williamson E. G, Stover R D, Fiss C B. Testing for nursing aptitude. The Parrot, the yearbook of the Memorial Hospital School of Nursing, Rhode Island, July 1937.

3. Wright S R, Bradley P M. Has the UK clinical aptitude test improved medical studentselection? Journal of Medical Education. 2010:44 (11); 1069-76.

4. Berman A, Snyder S,Kozier B, Erb G. Kozier and Erb's fundamentals of nursing. $18^{\text {th }}$ edition. Delhi: Dorling Kindersley Pvt. Ltd; 2008

5. Indian Nursingyearbook. 1993-95.

6. Andrade M. Perceptions of health care consumers, deliverers and nurse educators on nurses, nursing practice and nursing education system. Manipal University, M anipal: 2010.

7. Pataliah B A. Aptitude towards nursing among nursing professionals. The Nursing Journal of India. 2004; 95 (11): 253- 257

8. Newton S E, Moore G. Use of aptitude to understand bachelor of science in nursing student attrition and readiness for the national council licensure examination - registered nurse. Journal of professional nursing. 2009: 25(5); 273-278.

9. Newton S E, Harris M, Pittiligo L, Moore G. Nursing student math aptitude and success on a medication calculation assessment. Nurse educator. 2009: 34(2); 80-83.

10. M agno C. Integrating Nursing Quality with Achievement and Aptitude: Towards Assessing Nursing Potential. The International Journal of Research and Review. Vol 4, 2010

11. Swanson K M. Empirical development of a middle range theory of caring. Nursing research. 1991 M ay June; 40 (3): 161-166.

12. Jiwan T. Aptitude test for students seeking admission to nursing institutes. The nursing journal of India. 2011; 102(8): 174-175.

13. Andrade M. Choice of nursing career: Pleasure or pressure. International journal of nursing education. 2012; 4(1): 42-44

14. M c.Donald D. Testing for competence rather than for intelligence. American Psychologist. Jan 1973; 1-14

15. Watson J. Assessing and measuring caring in nursing and health sciences. $2^{\text {nd }}$ ed. New York: Springer publishing company; 2009. 